Fixed Point Theory, 23(2022), No. 1, 85-104

DOI: $10.24193 /$ fpt-ro.2022.1.06

http://www.math.ubbcluj.ro/ nodeacj/sfptcj.html

\title{
ON EXISTENCE RESULTS IN FIXED SET THEORY AND APPLICATIONS TO SELF-SIMILARITY
}

\author{
KHALED BEN AMARA*, AREF JERIBI** AND NAJIB KADDACHI*** \\ *Department of Mathematics, University of Sfax, Faculty of Sciences of Sfax, \\ Soukra Road Km 3.5 B.P. 1171, 3000, Sfax, Tunisia \\ E-mail: khaledamaram@gmail.com \\ ** Department of Mathematics, University of Sfax, Faculty of Sciences of Sfax, \\ Soukra Road Km 3.5 B.P. 1171, 3000, Sfax, Tunisia \\ E-mail: Aref.Jeribi@fss.rnu.tn \\ *** Department of Mathematics, University of Sfax, Faculty of Sciences of Sfax, \\ Soukra Road Km 3.5 B.P. 1171, 3000, Sfax, Tunisia \\ E-mail: najibkadachi@gmail.com
}

Abstract. In this manuscript, by removing the domain convexity hypothesis, the existence of
fixed set results for the sum and the product of $(p+1)$-multi-valued operators $\sum_{i=1}^{p} A \cdot B_{i}$, acting on
Banach algebras satisfying a sequential condition $(\mathcal{P})$ under weak topology is proved. In addition, by Banach algebras satisfying a sequential condition $(\mathcal{P})$ under weak topology is proved. In addition, by
using a new definition of the multi-valued operator $\left(\frac{I}{A}\right)$, we obtain new fixed-set theorems for the

operators of the form $\left(\frac{I}{A}\right)^{-1} \sum_{i=1}^{p} B_{i}$ under some suitable conditions on the operators $A, B_{1}, \ldots, B_{p}$. Applications to self-similarity theory are also given.

Key Words and Phrases: Banach algebra, weakly sequentially continuous, measure of weak noncompactness, fixed-set theory.

2020 Mathematics Subject Classification: 47H10, 45G15.

\section{REFERENCES}

[1] J. Appell, E. De Pascale, Some parameters associated with the Hausdorff measure of noncompactness in spaces of measurable functions, (Italien), Boll. Un. Mat. Ital. B. (6), 3(1984), no. 2, 497-515.

[2] J. Banaś, M. Lecko, Fixed points of the product of operators in Banach algebras, Pan Amer. Math. J., 12(2002), no. 2, 101-109.

[3] J. Banaś, O. Leszek, On the equivalence of some concepts in the theory of Banach algebras, Ann. Funct. Anal., 10(2019), no. 2, 277-283.

[4] J. Banaś, L. Olszowy, On a class of measures of noncompactness in Banach algebras and their application to nonlinear integral equations, Z. Anal. Anwend., 28(2009), no. 4, 475-498.

[5] J. Banaś, J. Rivero, On measures of weak noncompactness, Ann. Mat. Pura Appl., 151(1988), no. $4,213-224$ 
[6] J. Banaś, B. Rzepka, Monotonic solutions of a quadratic integral equation of fractional order, J. Math. Anal. Appl., 332(2007), no. 2, 1371-1379.

[7] J. Banaś, K. Sadarangani, Solutions of some functional-integral equations in Banach algebras, Math. Comput. Modelling, 38(2003), no. 3-4, 245-250.

[8] A. Ben Amar, I. Ben Hassine, M. Boumaiza, Hybrid fixed-set results for multivalued mappings in Banach algebras under a weak topology setting, Numer. Funct. Anal. Optim., 40(2019), no. 6, 706-725.

[9] A. Ben Amar, M. Boumiza, D. O'Regan, Hybrid fixed point theorems for multivalued mappings in Banach algebras under a weak topology setting, J. Fixed Point Theory Appl., 18(2016), no. $2,327-350$.

[10] A. Ben Amar, S. Chouayekh, A. Jeribi, New fixed point theorems in Banach algebras under weak topology features and applications to nonlinear integral equations, J. Funct. Anal., 259(2010), no. 9, 2215-2237.

[11] A. Ben Amar, S. Chouayekh, A. Jeribi, Fixed point theory in a new class of Banach algebras and application, Afrika Mat., 24(2013), no. 4, 705-724.

[12] D.W. Boyd, J.S.W. Wong, On nonlinear contractions, Proc. Amer. Math. Soc., 20(1969), 458464.

[13] J. Caballero, B. Lopez, K. Sadarangani, Existence of nondecreasing and continuous solutions of an integral equations with linear modification of the argument, Acta Math. Sin. (Engl. Ser.), 23(2007), no. 9, 1719-1728.

[14] J.B. Conway, A Course in Functional Analysis, Graduate Texts in Mathematics, 96. SpringerVerlag, New York, 1990.

[15] F.S. De Blasi, On a property of the unit sphere in a Banach space, Bull. Math. Soc. Sci. Math. R.S. Roumanie (N.S.), 21(69)(1977), no. 3-4, 259-262.

[16] B.C. Dhage, Remarks on two fixed-point theorems involving the sum and the product of two operators, Comput. Math. Appl., 46(2003), no. 12, 1779-1785.

[17] B.C. Dhage, A fixed point theorem in Banach algebras involving three operators with applications, Kyungpook Math. J., 44(2004), no. 1, 145-155.

[18] B.C. Dhage, Fixed-point theorems for discontinuous multivalued operators on ordered spaces with applications, Comput. Math. Appl., 51(2006), no. 3-4, 589-604.

[19] B.C. Dhage, On some nonlinear alternatives of Leray-Schauder type and functional integral equations, Arch. Math. (Brno), 42(2006), no. 1, 11-23.

[20] J.E. Hutchinson, Fractals and self-similarity, Indiana Univ. Math. J., 30(1981), no. 5, 713-747.

[21] A. Jeribi, N. Kaddachi, B. Krichen, Existence results for a coupled system of perturbed functional differential inclusions in Banach algebras, Bull. Malays. Math. Sci. Soc., 41(2018), no. 2, 893918.

[22] A. Jeribi, B. Krichen, Nonlinear Functional Analysis in Banach Spaces and Banach Algebras: Fixed Point Theory Under Weak Topology for Nonlinear Operators and Block Operator Matrices with Applications, Monographs and Research Notes in Mathematics, CRC Press Taylor and Francis, 2015.

[23] K. Ben Amara, A. Jeribi, N. Kaddachi, New fixed point theorems for countably condensing maps with an application to functional integral inclusions, Math. Slovaca. 71(2021), No. 6, 1-24.

[24] A. Fahem, A. Jeribi, N. Kaddachi, it Existence of Solutions for a System of Chandrasekhars Equations in Banach algebras under weak topology, Filomat 33(2019); no:18; 5949-5957.

[25] A. Jeribi, N. Kaddachi, Z. Laouar, Fixed point theorems for weakly asymptotically regular mappings in Banach spaces with an application, to appear in Numerical Functional Analysis and Optimization.

[26] N. Kaddachi, A. Jeribi, B. Krichen, Fixed Point Theorems of Block Operator Matrices OnBanach Algebras and an Application to Functional Integral Equations, Math. Methods Appl. Sci. 36(2013); 659-673.

[27] N. Kaddachi, Existence results of ordinary differential inclusions in Banach algebra under weak topology, J. Phys. Math. 9(2018), DOI: 10.4172/2090-0902.1000285.

[28] N. Kaddachi, Generalized form of fixed point theorems in Banach algebras under weak topology with an application, Filomat 33(2019), 4281-4296. 
[29] N. Kaddachi, A. Jeribi, B. Krichen, Fixed point theorems for multivalued operator matrices under weak topology with application, Bull. Malays. Math. Sci. Soc. 43(2020), no. 2, 1047-1067.

[30] R.W. Legget, On certain nonlinear integral equations, J. Math. Anal. Appl., 57(1997), no. 2, 462-468.

[31] A. Majorana, S.A. Marano, Continuous solutions of a nonlinear integral equation on an unbounded domain, J. Integral Equations Appl., 6(1994), no. 1, 119-128.

[32] B.B. Mandelbrot, Fractals: Form, Chance, and Dimension, translated from French, W.H. Freeman and Co., San Francisco, Califonia, 1977.

[33] G. Moţ, A. Petruşel, G. Petruşel, Topics in Nonlinear Analysis and Applications to Mathematical Economics, Casa Cărţii de Ştiinţă, Cluj-Napoca, 2007.

[34] E.A. Ok, Fixed set theory for closed correpondences with applications to self similarity and games, Nonlinear Anal. 56(2004), no. 3, 309-330.

[35] E.A. Ok, Fixed set theorems of Krasnoselskii type, Proc. Amer. Math. Soc. 137(2009), no. 2, 511-518.

Received: July 6, 2020; Accepted: April 9, 2021. 
KHALED BEN AMARA, AREF JERIBI AND NAJIB KADDACHI 